\title{
Improving the Antioxidant Properties of Fermented Camel Milk Using Some Strains of Lactobacillus
}

\author{
Mahmoud Ibrahim El-Sayed ${ }^{*}$, Sameh Awad ${ }^{2}$, Nagwa Hussein Ismail Abou-Soliman ${ }^{3}$ \\ ${ }^{1}$ Department of Dairy Technology Research, Food Technology Research Institute, ARC, Giza, Egypt \\ ${ }^{2}$ Dairy Microorganisms and Cheese Research Laboratory (DMCR), Department of Dairy Science and Technology, Faculty of \\ Agriculture, Alexandria University, Alexandria, Egypt \\ ${ }^{3}$ Animal Breeding Department, Animal and Poultry Production Division, Desert Research Centre, Matariya, Cairo, Egypt \\ Email: ^mahmoud_im1981@yahoo.com,mahmoud.elsayed@arc.sci.eg
}

How to cite this paper: El-Sayed, M.I., Awad, S. and Abou-Soliman, N.H.I. (2021) Improving the Antioxidant Properties of Fermented Camel Milk Using Some Strains of Lactobacillus. Food and Nutrition Sciences, $12,352-371$.

https://doi.org/10.4236/fns.2021.124028

Received: March 3, 2021

Accepted: April 12, 2021

Published: April 15, 2021

Copyright $\odot 2021$ by author(s) and Scientific Research Publishing Inc. This work is licensed under the Creative Commons Attribution International License (CC BY 4.0).

http://creativecommons.org/licenses/by/4.0/

\begin{abstract}
This study aimed at improving the antioxidant capacity of fermented camel milk using some single strains of Lactobacillus (Lb. helveticus B-734, Lb. casei subsp. casei B-1922, Lb. paracasei subsp. paracasei B-4560, Lb. rhamnosus B-1445 or Lb. rhamnosus B-442), as well as evaluating the acceptability of the final products. The acidity, proteolysis degree, antioxidant activity, viscosity and organoleptic properties of fermented milk were assessed during 14 days of storage at $4^{\circ} \mathrm{C}$. Total phenolic content (TPC), DPPH radical scavenging activity, Ferrous ion chelating ability (FCA) and Ferric reducing antioxidant power (FRAP) assays were used to determine the antioxidant activity of fermented milks. The results indicated that fermented milks differed significantly $(\mathrm{P}<0.05)$ in all studied parameters due to the type of starter culture used. During storage period, samples containing $L b$. helveticus had the highest proteolysis degree, while samples with commercial starter culture (control) showed the lowest degree of proteolysis. Fermented milks containing Lactobacillus strains showed higher DPPH radical scavenging activity compared to those samples containing commercial starter culture. By the end of storage, there was a significant improvement $(\mathrm{P}<0.05)$ in scavenging activity for all fermented milk samples. Regarding FCA, at the beginning of storage fermented milks containing $L$ b. paracasei, $L$ b. rhamnosus B-442 or commercial starter culture had the highest FCA values, while $L b$. rhamnosus B-1445 samples recorded the highest value at the end of storage. Lb. helveticus samples had the highest TPC and FRAP values $(\mathrm{P}<0.05)$ throughout the storage. There was a high significant correlation $(\mathrm{P}<0.0001)$ between the proteolysis degree and the values of FRAP and TPC. Samples containing Lb. rhamnosus
\end{abstract}


B-442, Lb. rhamnosus B-1445 or commercial starter culture received the highest taste and overall acceptability scores while $L b$. helveticus samples were the lowest. It is recommended to use $L b$. rhamnosus B-442 and $L b$. rhamnosus B-1445 for producing fermented camel milk with high antioxidant activity and acceptability.

\section{Keywords}

Camel Milk, Fermented Milk, Antioxidant Activity, Lactobacillus

\section{Introduction}

Camels (Camelus dromedarius) are very important to many pastoral communities in dry zones by providing milk, meat and transportation. The global camel population is estimated to be around 32.6 million, and most of these camels are found in African countries such as Somalia, Sudan, Chad, and Kenya [1]. Camel milk (CM) can be considered as one of the alternatives to Bovine milk (BM) with enhanced functions and better digestibility than BM in the human gastrointestinal system [2]. Camel milk not only provides the required nutrition for people, but also offers several therapeutic properties [3]. Camel milk has been known as a source for the production of dairy products with excellent therapeutic properties [4].

Fermented camel milk is proven to have many health benefits such as anti-inflammatory, antimicrobial, antioxidant, anticancer, hypocholesterolemic effect, anti-diarrhea activity, angiotensin I-converting enzyme (ACE) inhibitory activity [5] [6]. Thus, fermented camel milk has been proven as a therapeutic product [7]. In addition to providing energy and nutrients, fermented camel milk is an excellent source of bioactive peptides [8].

Bioactive peptides can be derived from enzymatic hydrolysis and/or microbial proteolytic activities during milk fermentation. These peptides have specific biological activities [9], such as antioxidant, antimicrobial, antihypertensive, ACE inhibitory, immunomodulant, and mineral binding [10] [11]. The antioxidant effect of peptides includes radical-scavenging (both hydrogen-donating capability and free radical quenching) activity, inhibition of lipid peroxidation, metal ion chelation, or all of these properties [12]. The mode of action of these peptides is due to the composition and amino acids sequence [13]. Antioxidant activity is known to be affected by the sequence and exposure of terminal amino acids of peptides after protein hydrolysis [14]. The peptides with antioxidant activity usually consist of 5 - 11 amino acids, including hydrophobic amino acids as proline, histidine, tyrosine and tryptophan [15].

Lactic acid bacteria (LAB) are known for many health benefits and industrial importance. In addition, LAB used as starters are primarily responsible for the generation of bioactive peptides during milk fermentation [6]. The proteolytic system of LAB involved in casein utilization provides cells with essential amino 
acids during growth in milk. It is also of industrial importance due to its contribution to the development of the organoleptic properties of fermented milk product [16]. Also, proteolytic system of LAB is possessed of an extracellular located serine proteinase, a transport system specific for di-, tri-, and oligopeptides, and a multitude of intracellular peptidases. Proteinases of lactic acid bacteria may hydrolyze more than $40 \%$ of the peptide bonds of as1- and $\beta$-caseins, producing oligopeptides of 4 to 40 amino acid residues [17] [16]. Naturally, camel milk is a blend of many bio-functional components. Camel milk contains all essential nutrients on which lactic acid bacteria can readily act and produce many bio-functional components which give health benefits to the consumer [18]. In addition, after fermentation of camel milk the concentrations of free amino acids, fatty acids and organic acid were increased. Many studies found that antioxidative peptides were derived during the fermentation of camel milk [2] [12] [19] [20]. Kansci et al. [21] found that, during the gastrointestinal digestion or fermentation of bovine milk $\beta$-Casein, radical scavenging bioactive peptides were produced. Moslehishad et al. [22] found that the antioxidant activity of camel milk fermented with Lactobacillus rhamnosus PTCC1637 was higher than fermented bovine milk. Also, Salami et al. [23] reported that, the antioxidant activity of camel $\beta$-CN was significant increased after enzymatic hydrolysis with chymotrypsin. The objectives of the current study were to investigate the effect of proteolytic activity of some Lactobacillus strains on the antioxidant capacity of fermented camel milk, and to evaluate the acceptability of the final products.

\section{Materials and Methods}

\subsection{Materials}

Camel milk was obtained from Camel Research Center, Marsa Matrouh, Egypt. Lyophilized Lactobacillus ( Lb.) strains (Lb. helveticus B-734, Lb. casei subsp. casei B-1922, Lb. paracasei subsp. paracasei B-4560, Lb. rhamnosus B-1445 and $L b$. rhamnosus B-442) were supplied by the Agriculture Research Service (ARS) Culture Collection, Norwegian Radio Relay League (NRRL) Peoria, USA. Commercially-available lyophilized culture (Express 0.2, DVS) was purchased from Chr. Hansen Laboratories, Copenhagen, Denmark. Modified starch ETENIA ${ }^{\text {tm }}$ 457 was obtained from AVEBE, Veendam, Netherlands. Ferrous sulphate $\left(\mathrm{FeSO}_{4} \cdot 7 \mathrm{H}_{2} \mathrm{O}, 20.09 \%\right.$ iron) was obtained from Fisons Laboratory Reagent, England. 1, 1-diphenyl-2-picryl-hydrazyl (DPPH) was purchased from Sigma-Aldrich (Munich, Germany). Ferric chloride, potassium ferricyanide and gallic acid were obtained from Loba Chemie, Mumbai, India.

\subsection{Methods}

\subsubsection{Cultures Preparation}

Lyophilized bacterial strains were activated in $10 \mathrm{~mL}$ of de Man, Rogosa, Sharpe (MRS) broth at $37^{\circ} \mathrm{C}$ for $24 \mathrm{hr}$. Then, $1 \mathrm{~mL}$ of each culture was added to $100 \mathrm{~mL}$ 
of MRS broth and incubated at $37^{\circ} \mathrm{C}$ for $24 \mathrm{hr}$. One $\mathrm{mL}$ of each culture was inoculated into $100 \mathrm{~mL}$ of autoclaved reconstituted skimmed milk powder (11\%) and incubated at $37^{\circ} \mathrm{C}$ overnight and used for preparation of fermented milks.

\subsubsection{Preparation of Fermented Milk}

Camel milk (total solids $12.37 \%$, protein $3.21 \%$, fat $4.1 \%, \mathrm{pH} 6.54$, and acidity $0.170 \%)$ was divided into six parts. Modified starch $(0.5 \%$; w $/ \mathrm{v})$ was added to each part of milk before heat treatment. Fermented milk was prepared according to Tamime and Robinson [24]. All milks were heated separately at $90^{\circ} \mathrm{C}$ for 10 min and rapidly cooled to $42^{\circ} \mathrm{C}$. The first part was inoculation with $0.04 \%(\mathrm{w} / \mathrm{v})$ of commercial starter culture alone (as control). Each of the other five parts of milk was inoculated with $3 \%(\mathrm{v} / \mathrm{v})$ of single strain of Lactobacillus ( $\mathrm{Lb}$. helveticus B-734, Lb. casei subsp. casei B-1922, Lb. paracasei subsp. paracasei B-4560, Lb. rhamnosus B-1445 and Lb. rhamnosus B-442). Fermentation was carried out at $40^{\circ} \mathrm{C}$ until the $\mathrm{pH}$ reached 4.69 with samples containing the commercial starter culture (control), Lb. casei, and Lb. rhamnosus B-442. While, the $\mathrm{pH}$ values for samples containing Lb. helveticus, Lb. paracasei, and Lb. rhamnosus B-1445 were 5.05, 4.82 and 4.46 , respectively. Then, the fermented milks were stored at $4^{\circ} \mathrm{C} \pm 1^{\circ} \mathrm{C}$ for 14 days.

\subsubsection{Chemical Composition}

Camel milk was analyzed for total solids (\%), protein (\%) and fat (\%) using the AOAC procedures [25]. The $\mathrm{pH}$ of milk was measured using a digital $\mathrm{pH}$ meter (Martini, Italy). Titratable acidity (lactic acid \%) of raw and fermented camel milks was evaluated by titration with $0.1 \mathrm{~N} \mathrm{NaOH}$ in the presence of phenolphthalein as an indicator. All analyses were performed in triplicate.

\subsubsection{Preparation of Water-Soluble Extracts from Fermented Milks}

Water-soluble extracts were prepared in accordance with the method of Shori and Baba [26]. Fermented milk samples (10 g) were homogenized with $2.5 \mathrm{ml}$ of distilled water then acidified to $\mathrm{pH} 4.0$ with $0.1 \mathrm{M} \mathrm{HCl}$, followed by holding at $45^{\circ} \mathrm{C}$ for $10 \mathrm{~min}$ and centrifugation at $10,000 \mathrm{~g}$ for $10 \mathrm{~min}$ at $4^{\circ} \mathrm{C}$. The $\mathrm{pH}$ of supernatants was adjusted to $\mathrm{pH} 7.0$ using $0.1 \mathrm{M} \mathrm{NaOH}$ and re-centrifuged $(10,000$ $\mathrm{g}, 10 \mathrm{~min} / 4^{\circ} \mathrm{C}$ ) for further precipitation of proteins and salts. The supernatants were collected and kept at $-20^{\circ} \mathrm{C}$ for further analyses.

\subsubsection{Determination of Proteolysis Degree}

\section{1) Cadmium-ninhydrin assay}

Total free amino groups in water-soluble extract were assessed by the Cadmium-ninhydrin method described by Folkertsma and Fox [27]. The concentrations of total free amino groups were quantified against a standard curve of leucine $(0.0-0.3 \mathrm{mM})$. Results were expressed as leucine equivalent in $\mathrm{mM} / \mathrm{mL}$ extract. All determinations were performed in triplicate.

2) Sodium dodecyl sulphate polyacrylamide gel electrophoresis (SDS-PAGE)

SDS-PAGE, $12.5 \% \mathrm{~T}$, was conducted under reducing conditions using the 
discontinuous buffer system described by Laemmli [28]. SDS-PAGE was performed on fermented camel milk samples using a Mini-PROTEAN electrophoresis cell (Bio-Rad Laboratories, Hercules, CA, USA). Five grams of each sample were stirred with cold acetone $(30 \mathrm{~mL})$ for $10 \mathrm{~min}$ to get rid of the fat and left to dry at room temperature. The dried powdered fermented milk sample $(20 \mathrm{mg})$ was mixed with $500 \mu \mathrm{L}$ of sample buffer. Samples were denatured by boiling for $5 \mathrm{~min}$, and then $5 \mu \mathrm{L}$ of each sample was injected. The data were analyzed by Total Lab software (V1.11).

\subsubsection{Determination of Antioxidant Activity}

\section{1) Determination of total phenolic content}

Total phenolic contents (TPC) of water-soluble extracts were determined in triplicate using the method developed by Abirami et al. [29]. One and half milliliters of Folin-Ciocalteu's reagent (diluted 10 times) and $1.2 \mathrm{~mL}$ of $\mathrm{Na}_{2} \mathrm{CO}_{3}(7.5 \%$ w/v) were added to $300 \mu \mathrm{L}$ of water-soluble extract. Mixtures were shaken and kept at room temperature for $30 \mathrm{~min}$ before measuring absorbance at $765 \mathrm{~nm}$ using a spectrophotometer (Pg T80+, England). TPC was expressed as mg gallic acid equivalents (GAE)/mL extract.

\section{2) DPPH radical scavenging activity assay}

Scavenging activity of the stable 1, 1-diphenyl-2-picrylhydrazyl (DPPH) radical was determined in triplicate according to the procedure described by Lim and Quah [30]. Two milliliters of $0.15 \mathrm{mM}$ DPPH dissolved in methanol were added to 1 mLof water-soluble extracts, mixed well and left in the dark for 30 min at room temperature. Absorbance (Abs) was measured at $517 \mathrm{~nm}$ against distilled water as a blank using a spectrophotometer (Pg T80+, England). Control was prepared by adding $2 \mathrm{~mL}$ of DPPH to $1 \mathrm{~mL}$ of methanol. The radical scavenging activity of extracts was calculated as follows

$$
\text { Radical scavenging activity } \%=\left(1-\text { Abs }_{\text {sample }} / \mathrm{Abs}_{\text {control }}\right) \times 100
$$

\section{3) Ferrous ion chelating assay}

Ferrous ion chelating assay (FCA) was carried out as described by Chan et al. [31]. A freshly prepared ferrous sulphate hydrate $\left(\mathrm{FeSO}_{4} \cdot \mathrm{xH}_{2} \mathrm{O}\right)$ solution $(2 \mathrm{mM})$ and ferrozine solution $(5 \mathrm{mM})$ were both diluted 20 times before using. Diluted $\mathrm{FeSO}_{4} \cdot \mathrm{xH}_{2} \mathrm{O}(1 \mathrm{~mL})$ was mixed with samples of water-soluble extracts $(1 \mathrm{~mL})$. Diluted ferrozine $(1 \mathrm{~mL})$ was then added to the mixture followed by incubation for $10 \mathrm{~min}$ at room temperature. Absorbance (Abs) was measured at $562 \mathrm{~nm}$ against distilled water as blank using a spectrophotometer (Pg T80+, England). The absorbance of control was determined similarly by replacing the supernatant with distilled water. The ferrous ion chelating ability (FCA) of extracts was determined in triplicate and calculated using the equation:

$$
\text { FCA } \%=\left(1-\text { Abs }_{\text {sample }} / \mathrm{Abs}_{\text {control }}\right) \times 100
$$

\section{4) Ferric reducing antioxidant power}

Ferric ion reducing antioxidant power (FRAP) was determined according to 
Oyaizu [32]. One milliliter of extracts was added to $2.5 \mathrm{~mL}$ of phosphate buffer $(0.1 \mathrm{M}, \mathrm{pH} 6.6)$ and $2.5 \mathrm{~mL}$ of potassium ferricyanide $(1 \% \mathrm{w} / \mathrm{v})$. The mixture was then incubated in a water bath at $50^{\circ} \mathrm{C}$ for $20 \mathrm{~min}$ followed by cooling to room temperature and adding $2.5 \mathrm{~mL}$ of trichloroacetic acid $(10 \% \mathrm{w} / \mathrm{v})$. The contents of the tubes were centrifuged at $10,000 \times \mathrm{g}$ at $4^{\circ} \mathrm{C}$ for $10 \mathrm{~min}$. Next, $2.5 \mathrm{~mL}$ of supernatant was removed from each tube, and mixed with $2.5 \mathrm{~mL}$ of distilled water and $0.5 \mathrm{~mL}$ of ferric chloride solution $(0.1 \% \mathrm{w} / \mathrm{v})$. The mixtures were allowed to stand for $30 \mathrm{~min}$ then absorbance was measured at $700 \mathrm{~nm}$ using UV/ Visible spectrophotometer, Pharmacia-LKB-Ultrospec III (Pharmacia, USA). The assay was done in triplicate. The FRAP values, expressed in $\mathrm{mg} \mathrm{GAE} / \mathrm{mL}$ extract, were derived from a standard curve.

\subsubsection{Determination of Viscosity}

The viscosity of fermented camel milk was measured in triplicate at $10^{\circ} \mathrm{C} \pm 1{ }^{\circ} \mathrm{C}$ using oscillatory viscometer (VR 3000M YR Viscometers, Spain), using spindle 2 at speed of $60 \mathrm{rpm}$.

\subsubsection{Sensory Evaluation}

Fermented milks were evaluated for color, taste, consistency and overall acceptability. The evaluation was conducted by 9 panelists, with experience in sensory evaluation of dairy products, from the Department of Dairy Science and Technology, Faculty of Agriculture, Alexandria University. Samples were presented cooled in plastic cups for sensory evaluation after 1, 7, and 14 days of refrigerated storage. Water was provided between evaluations of samples for mouth rinsing. The evaluation was determined using a 9-point hedonic scale (1 dislike extremely, 9 like extremely).

\subsubsection{Statistical Analysis}

The data were analyzed by a general linear model procedure (GLM) using SAS statistical analysis software package (SAS Procedure Guide "Version 6.12 Ed." SAS Institute Inc., Cary, 2004). The statistical analysis was performed using one-way analysis of variance (ANOVA). Means were compared by Duncan's test at the significance level of $\mathrm{P} \leq 0.05$. Pearson's correlation coefficient was used to calculate the correlation.

\section{Results and Discussion}

\subsection{Acidity}

The acidity in fermented camel milk is related to the metabolic activity of the LAB. The changes in acidity (\% lactic acid) of fermented camel milks prepared using single strains of lactobacillus during cold storage $\left(14\right.$ days $\left./ 4^{\circ} \mathrm{C}\right)$ are shown in Figure 1 . On the $1^{\text {st }}$ day of storage, lower acidity values were observed in the fermented milks containing Lb. helveticus, Lb. rhamnosus B-442 and Lb. casei, while, higher acidity values were found in $L b$. rhamnosus B-1445, Lb. paracasei and commercial starter culture samples. On $7^{\text {th }}$ day, samples containing $L b$. casei 


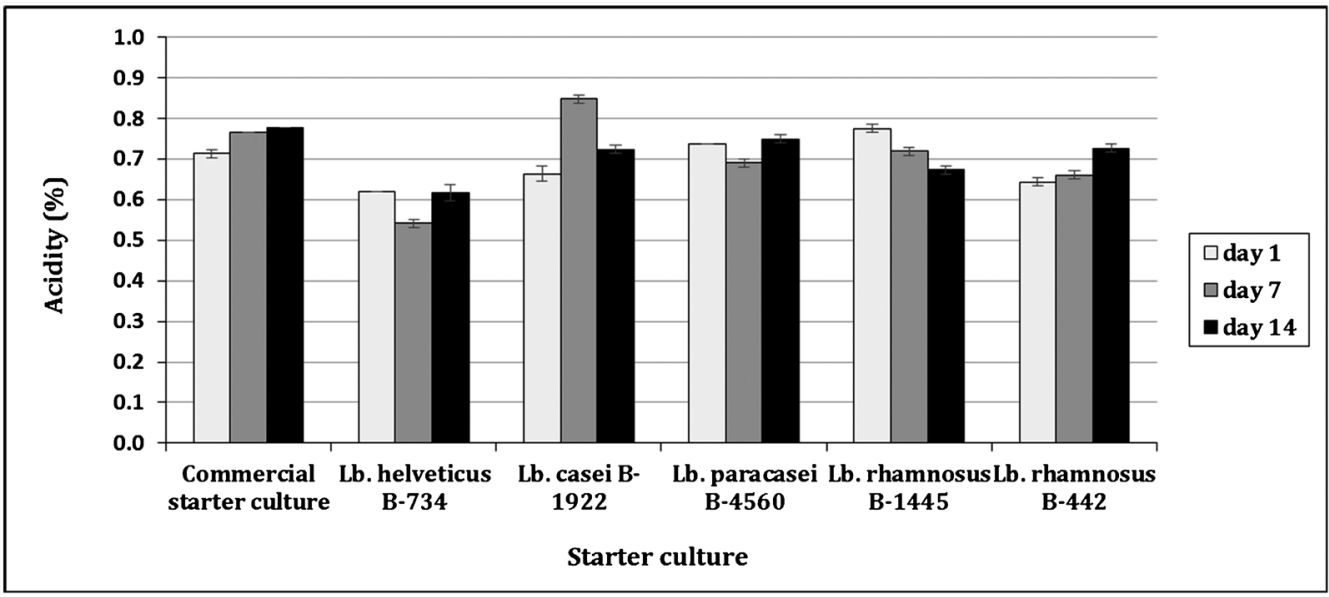

Figure 1. Changes in acidity (Mean values \pm SD) of fermented camel milks prepared using single strains of Lactobacillus during cold storage.

or commercial starter culture had the highest acidity values, while the lowest acidity value was observed in Lb. helveticus samples. At the end of storage period (14 days), the acidity values of fermented milks were in the following order: commercial starter culture $>L$ b. paracase $i=L b$. case $i=L b$. rhamnosus $\mathrm{B}-442>$ Lb. rhamnosus B-1445 > Lb. helveticus. From these results, it is clear that the fermented milk samples containing $L b$. helveticus had the lowest acidity values during storage. Fluctuations in acidity values during storage of fermented milks may be explained by the relative changes in the formation of organic acids and the alkaline nature of milk protein breakdown products [33]. Al-Sheraji et al. [34] noted that the diversity in acidity development in camel milk-derived products is due to the differences in proteolysis. The level of lactic acid production depends on the amount of fermentable sugar and milk protein hydrolyzed by lactic acid bacteria [35]. De-Oliveira [36] reported that change in acidity may due to differential activity and microbial population during fermentation and storage.

\subsection{Proteolysis Degree}

\subsubsection{Cadmium-Ninhydrin Assay}

Cadmium-ninhydrin method was used to estimate proteolysis in fermented milk during a 14-day storage period. Table 1 shows the proteolysis degree (mM leucine equivalent $/ \mathrm{mL}$ extract) in fermented milks prepared using commercial starter culture and some single strains of Lactobacillus. The results revealed that there were significant differences $(\mathrm{P}<0.05)$ in the degree of proteolysis among fermented milks, depending on the type of starter culture. During the storage period, fermented milks containing commercial starter culture had the lowest proteolysis degree, while samples with $L b$. helveticus showed the highest degree of proteolysis $(\mathrm{P}<0.05)$. Differences between treatments could be attributed to the variation between starter cultures in proteinase-endopeptidase activity [37]. Strains of $L b$. helveticus are known to have one of the most complex proteolytic 
Table 1. Proteolysis degree in fermented camel milk prepared with single strains of Lactobacillus during cold storage.

\begin{tabular}{cccc}
\hline \multirow{2}{*}{ Starter culture } & \multicolumn{3}{c}{$\begin{array}{c}\text { Total free amino groups } \\
(\mathrm{mM} \text { leucine equivalent/mL) }\end{array}$} \\
\cline { 2 - 4 } & Day 1 & Day 7 & Day 14 \\
\hline Commercial starter culture & $1.01 \pm 0.03^{\mathrm{eB}}$ & $1.17 \pm 0.06^{\mathrm{eA}}$ & $0.69 \pm 0.02^{\mathrm{dC}}$ \\
Lb. helveticus B-734 & $6.13 \pm 0.11^{\mathrm{aA}}$ & $4.51 \pm 0.10^{\mathrm{aB}}$ & $3.14 \pm 0.17^{\mathrm{aC}}$ \\
Lb. casei subsp. casei B-1922 & $1.26 \pm 0.07^{\mathrm{dC}}$ & $3.66 \pm 0.15^{\mathrm{cA}}$ & $2.26 \pm 0.17^{\mathrm{cB}}$ \\
Lb. paracasei subsp. paracasei B-4560 & $2.91 \pm 0.02^{\mathrm{bB}}$ & $3.93 \pm 0.08^{\mathrm{bA}}$ & $2.50 \pm 0.06^{\mathrm{bC}}$ \\
Lb. rhamnosus B-1445 & $2.93 \pm 0.17^{\mathrm{bA}}$ & $2.32 \pm 0.07^{\mathrm{dB}}$ & $2.12 \pm 0.07^{\mathrm{cB}}$ \\
Lb. rhamnosus $\mathrm{B}-442$ & $2.45 \pm 0.04^{\mathrm{cA}}$ & $2.22 \pm 0.22^{\mathrm{dA}}$ & $0.89 \pm 0.06^{\mathrm{Db}}$ \\
\hline
\end{tabular}

Mean values $( \pm \mathrm{SD})$ with different small letters within the same column are significantly different; means with different capital letters within the same row are significantly different $(\mathrm{P}<0.05)$.

systems among lactic acid bacteria [38]. On the first day the proteolysis degree was in the following order: Lb. helveticus $>$ Lb. rhamnosus $\mathrm{B}-1445=L$ b. paracasei $>$ Lb. rhamnosus $\mathrm{B}-442>L$ b. casei $>$ commercial starter culture. This arrangement differed on the $7^{\text {th }}$ day and was as follows: Lb. helveticus $>L b$. paracasei $>$ Lb. case $>$ Lb. rhamnosus $\mathrm{B}-1445=$ Lb. rhamnosus $\mathrm{B}-442>$ commercial starter culture. This arrangement did not differ much on the $14^{\text {th }}$ day. The results also showed a significant decrease $(\mathrm{P}<0.05)$ in the proteolysis degree in fermented milk containing $L b$. helveticus with increased storage time. Fermented milks containing $L b$. casei, $L b$. paracasei or commercial starter culture exhibited a maximum degree of proteolysis on the $7^{\text {th }}$ day which decreased at the end of storage. The proteolysis degree of the samples prepared using $L b$. rhamnosus B-1445 decreased on the $7^{\text {th }}$ day, then stabilized until the end of the storage. As for fermented milk containing $L b$. rhamnosus B-442, there were no significant differences between the $1^{\text {st }}$ and $7^{\text {th }}$ days in the degree of proteolysis, which decreased markedly $(\mathrm{P}<0.05)$ at day 14 .

\subsubsection{SDS-Polyacrylamide Gel Electrophoresis (SDS-PAGE)}

To determine the effect of lactobacillus strains on the degradation of camel milk proteins, samples of fermented milk at different times of storage were analyzed by SDS-PAGE (Figure 2). On the first day of storage, lower degree of proteolysis was observed in fermented milk containing commercial starter culture compared to the samples with single strains of lactobacillus. Meanwhile, Lb. helveticus showed higher proteolytic activity compared to other lactobacillus strains. On the $7^{\text {th }}$ day the degree of proteolysis increased in most samples, and higher proteolysis was observed with $L b$. helveticus and $L b$. casei samples. The lowest proteolysis was observed with samples containing commercial starter culture. On the $14^{\text {th }}$ day of storage the samples containing Lb. helveticus had the highest degree of proteolysis, while the lowest proteolysis was obtained with samples containing $L b$. casei or $L b$. paracasei. These results confirmed that the proteolytic 


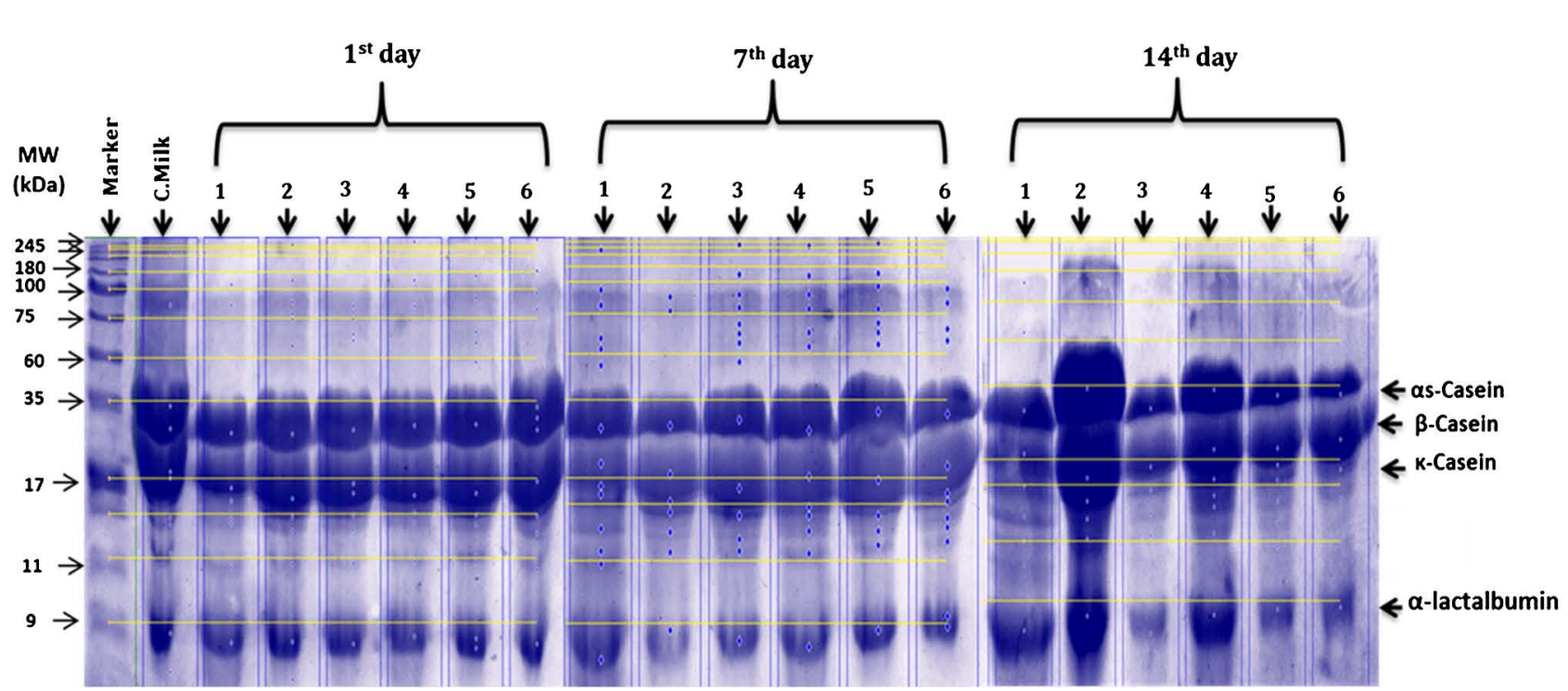

Figure 2. SDS-PAGE of fermented camel milk prepared using single strains of Lactobacillus during cold storage (14 days).C.Milk: Raw camel milk, 1: Lb. helveticus B-734 treatment, 2: Lb. casei subsp. casei B-1922 treatment, 3: Lb. rhamnosus B-1445 treatment, 4: Lb. paracasei subsp. paracasei B-4560 treatment, 5: Lb. rhamnosus B-442 treatment, 6: commercial starter culture treatment (control).

activity of most lactobacillus strains in this study increased with the increase in storage period and that the proteolytic activity of $L b$. helveticus was the highest among the other lactobacillus strains. These results are consistent with those of El-Zahar et al. [39], who observed that all proteins gradually degraded during the cold storage of the yogurt. They also noted that $\alpha \mathrm{s}_{1}$-casein was higher degraded than $\beta$-casein during the cold storage. The proteolytic behavior of lactobacillus strains in this study in agree with that found by Li et al. [40], who reported that the intensity of $\kappa$-, $\beta$-, and $\alpha$-casein bands in fermented milks were visually decreased during cold storage, meanwhile the electrophoretic bands referring to $\alpha$-Lactalbumin and $\beta$-Lactoglobulin were unaffected in all treatments.

\subsection{Antioxidant Activity}

\subsubsection{Total Phenolic Content}

Data in Figure 3 illustrate the effect of commercial starter culture and some strains of Lactobacillus on the total phenolic concentration of fermented camel milks during cold storage. The results showed that on the $1^{\text {st }}$ day of storage the samples containing $L b$. helveticus were the highest in TPC, while samples with commercial starter culture or $L b$. casei were the lowest. Samples containing commercial starter culture, Lb. casei or Lb. paracasei showed an increase in TPC on day 7. Whereas, on day 14 , the TPCs decreased significantly $(P<0.05)$ in all fermented milks except for samples containing $L b$. rhamnosus B-1445. The order of TPC in fermented milk samples was as follows: Lb. helveticus $>$ Lb. paracasei $>$ Lb. casei $>$ Lb. rhamnosus B-1445 > Lb. rhamnosus B- $442>$ commercial starter culture. The results also showed that TPC in fermented milk containing $L b$. helveticus was the greatest $(\mathrm{P}<0.05)$ throughout the storage compared to the other treatments. This result is related to the higher proteolytic activity of $L b$. 
helveticus. In this study, there was a highly significant correlation $(\mathrm{P}<0.0001)$ between the TPC and proteolysis degree. The decrease in TPC for fermented milk after 7 days of storage is in agreement with the results of Shori [35], who found that the TPC in plan camel yogurt was significantly decreased on day 7 , and increased on day 14 of storage. Moreover, the proteolysis of milk proteins during storage may result in the release of phenolic amino acids and non-phenolic compounds which may interfere during TPC determination [41].

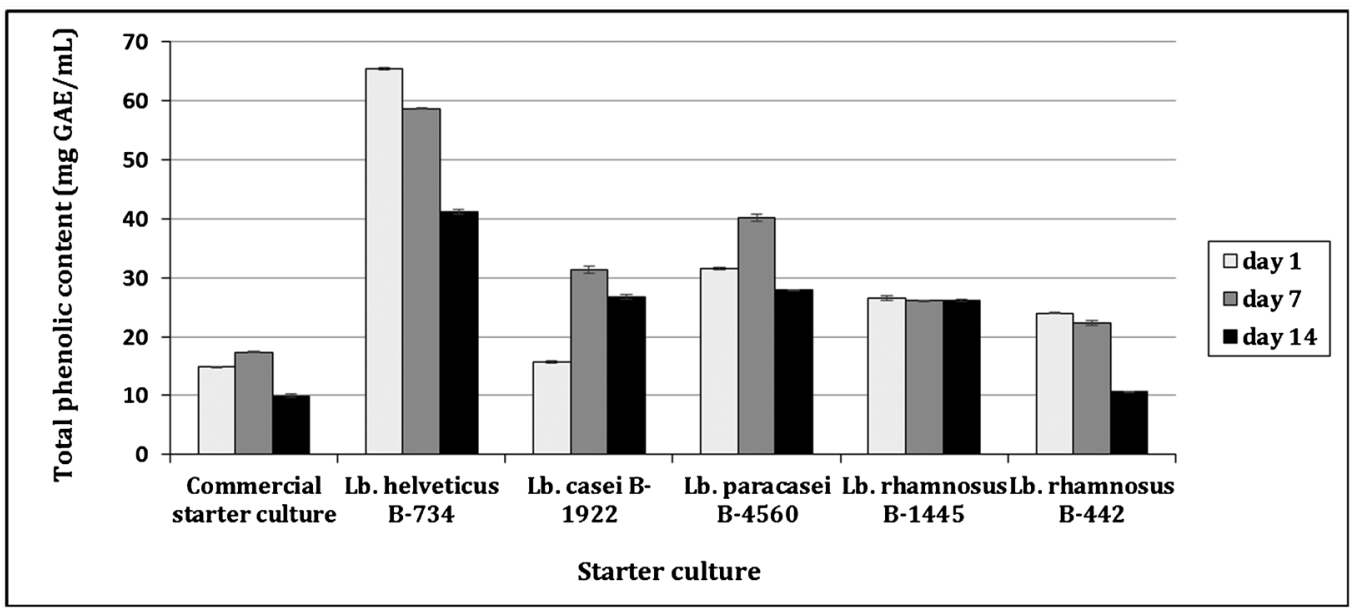

Figure 3. Changes in total phenolic content (Mean values \pm SD) of fermented camel milks prepared using single strains of Lactobacillus during cold storage.

\subsubsection{DPPH Radical Scavenging Activity}

DPPH radical scavenging activity of fermented milks prepared using single strains of Lactobacillus as well as commercial starter culture was presented in Figure 4. As evident, there were significant differences $(P<0.05)$ in the scavenging activity values among the fermented milks. In addition, fermented milk containing commercial starter culture exhibited lower DPPH radical scavenging activity compared to other fermented milks during storage. On the $1^{\text {st }}$ day, samples

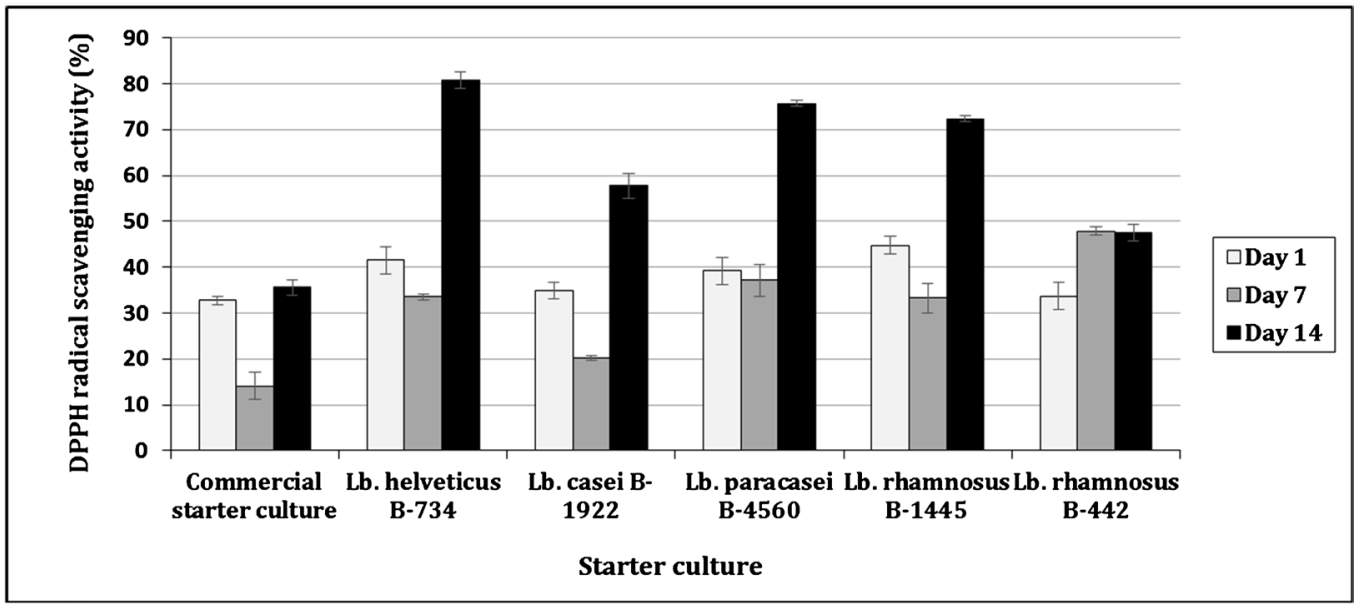

Figure 4. Changes in DPPH radical scavenging activity (Mean values \pm SD) of fermented camel milks prepared using single strains of Lactobacillus during cold storage. 
containing Lb. rhamnosus B-1445 or Lb. helveticus had the highest scavenging activity followed by samples with $L b$. paracasei or $L b$. casei, and then those containing $L b$. rhamnosus B-442 or commercial starter. On the $7^{\text {th }}$ day, the highest activity was for samples containing $L b$. rhamnosus B-442 followed by those containing Lb. paracasei, Lb. helveticus or Lb. rhamnosus B-1445 and then Lb. casei and finally the samples containing the commercial starter culture. On the $14^{\text {th }}$ day, the differences between samples were more pronounced compared to the $1^{\text {st }}$ and $7^{\text {th }}$ days of storage. The order of the samples in terms of activity was as follows: Lb. helveticus $>$ Lb. paracasei $>$ Lb. rhamnosus B-1445 $>$ Lb. casei $>$ Lb. rhamnosus B-442 > commercial starter. The results also revealed that the DPPH radical-scavenging activity for all fermented milks significantly decreased on day 7 of storage except for those samples containing Lb. rhamnosus B-442, which exhibited a significant increase $(\mathrm{P}<0.05)$ in scavenging activity, while the scavenging activity of fermented milk containing $L b$. paracasei was stable. At the end of storage period, there was a significant improvement $(P<0.05)$ in the scavenging activity for all fermented milk samples, particularly samples containing Lb. helveticus, $L b$. paracasei and Lb. rhamnosus B-1445. In this study, no significant correlation $(\mathrm{P}>0.05)$ was detected between the proteolysis degree and DPPH radical scavenging activity. This finding is consistent with the results of [42]. The absence of a relationship between the DPPH scavenging activity values and the degree of proteolysis indicates that the importance of the type and sequence position of functional amino acids in the peptides released for this activity [43] [44].

Overall, the antioxidant activity of fermented milk depends on various factors including the type and amount of the starter culture, the types of starter culture enzymes and the hydrolysis of proteins [45]. Further, the antioxidant properties of proteins and peptides count on many factors including the position of amino acids in their sequence as well as their physical structure, hydrophobicity and molecular weight [46].

\subsubsection{Ferrous Ion Chelating Ability}

Figure 5 presents the FCA of fermented milks prepared using single strains of lactobacillus during 14-day storage at $4^{\circ} \mathrm{C}$. The results showed that fermented milks differed significantly $(\mathrm{P}<0.05)$ in FCA due to the type of starter culture. On the $1^{\text {st }}$ day, samples containing $L b$. paracasei, Lb. rhamnosus B-442 or commercial starter culture recorded the highest FCA, while fermented milk containing $L b$. helveticus had the lowest FCA. After 7 days of storage, the FCA of samples containing $L b$. casei was the highest compared to other treatments, while fermented milk with $L b$. helveticus were still the lowest in chelating ability. The FCA of fermented milks was in the following order: samples containing $L b$. casei were higher than those containing $L b$. paracasei or commercial starter, followed by samples with $L b$. rhamnosus B-1445 or Lb. rhamnosus B-442, and then fermented milks with $L b$. helveticus. By the end of the storage period, the arrangement of samples differed completely in their ability to chelate iron. The FCA of 


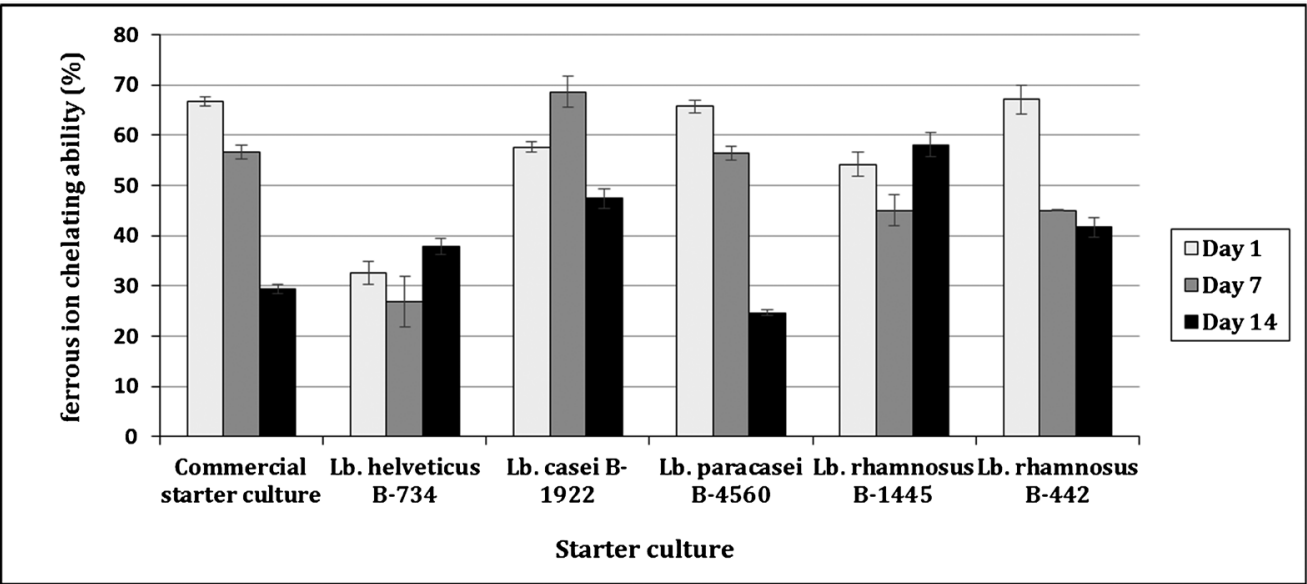

Figure 5. Changes in ferrous ion chelating ability (Mean values $\pm \mathrm{SD}$ ) of fermented camel milks prepared using single strains of Lactobacillus during cold storage.

fermented milks was in the following order: samples with $L b$. rhamnosus B-1445 > Lb. casei $>$ Lb. rhamnosus B-442 $>$ Lb. helveticus $>$ commercial starter culture $>L b$. paracasei. The FCA of fermented milks could be attributed to the iron-binding peptides that are generated from milk proteins due to the proteolytic activity of the starter cultures. The hydrolysis of milk proteins by LAB to release peptides that have the potential to bind minerals has been reported [47] [48]. The functional groups of amino acid residues within derived peptides such as phosphate, carboxyl, hydroxyl and methyl as well as aromatic rings act as binding sites for transition metals ions [49]. In addition, The N- and C-terminals of peptides have been reported to contribute the metal chelating activity [50]. The variations in FCA between fermented milks during storage could be attributed to the structure of peptides that are generated as a result of the proteolytic activities of starter cultures [47]. In current study, no significant correlation (P > 0.05) was detected between the high degree of proteolysis and the FCA. A similar relationship between the hydrolysis degree and FCA was stated by [51].

The FCA decreased significantly $(\mathrm{P}<0.05)$ for all fermented milks on the $7^{\text {th }}$ day, with the exception of samples containing $L b$. paracasei, where the ferrous chelating ability increased. On the $14^{\text {th }}$ day of storage, a marked improvement in the FCA values was observed in fermented milks with $L b$. helveticus and $L b$. rhamnosus B-1445. While there was a continuous decrease in the FCA in the samples containing $L b$. casei, $L b$. paracasei and commercial starter culture. Regarding $L b$. rhamnosus B-442 samples, the FCA was stable compared to day 7 of storage. A number of studies have found that the chelating capability of fermented milk samples increased with increased storage [45] [48].

\subsubsection{Ferric Reducing Antioxidant Power}

Data in Figure 6 illustrate the FRAP values of fermented camel milks prepared using single strains of lactobacillus during cold storage. On the $1^{\text {st }}$ day of storage, the greatest FRAP value $(0.322 \mathrm{mg} \mathrm{GAE} / \mathrm{mL})$ was found with $\mathrm{Lb}$. helveticus samples. While, on the $7^{\text {th }}$ day the highest FRAP values $(0.212,0.211$ and 0.206 


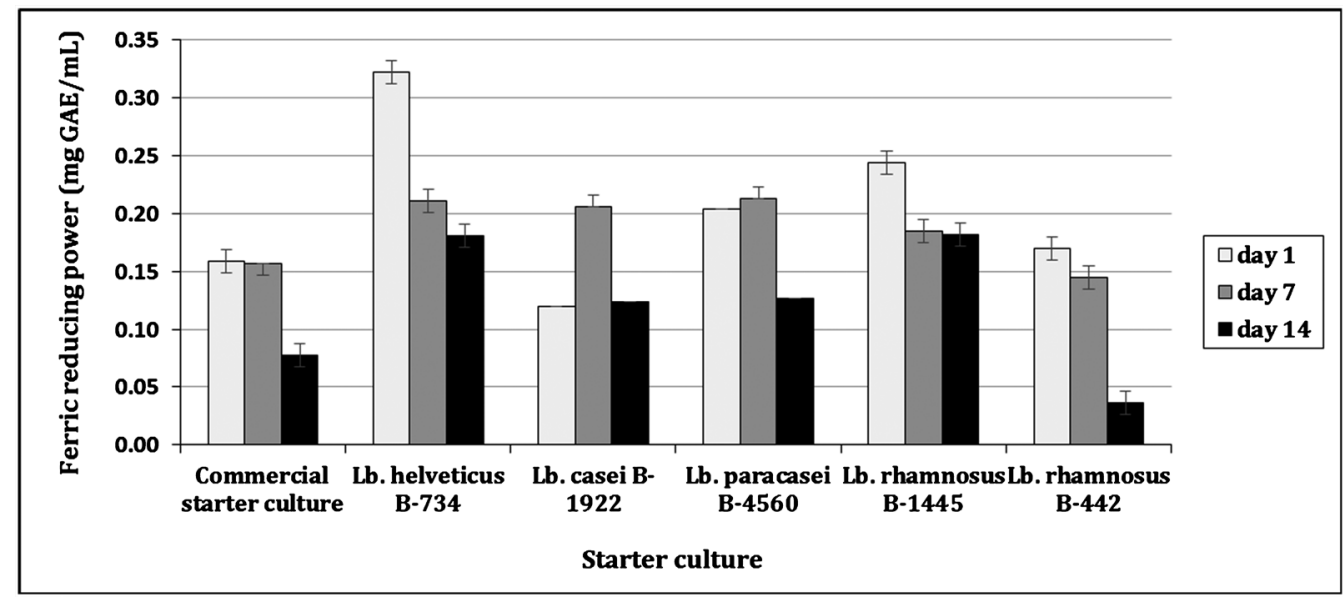

Figure 6. Changes in ferric reducing antioxidant power (Mean values \pm SD) of fermented camel milks prepared using single strains of Lactobacillus during cold storage.

mg GAE/mL) were observed with the samples containing $L$ b. paracasei, Lb. helveticus and $L b$. casei, respectively. On the $14^{\text {th }}$ day the highest FRAP values (0.180 and $0.181 \mathrm{mg} \mathrm{GAE} / \mathrm{mL}$ ) were found with Lb. helveticus and Lb. rhamnosus B-1445 samples, respectively. On the other side, fermented milk samples containing Lb. rhamnosus B-442 or commercial starter culture showed the lowest FRAP values throughout storage.

The results also showed that on the $7^{\text {th }}$ day of storage, fermented milks containing $L b$. casei showed a significant increase $(\mathrm{P}<0.05)$ in FRAP values. In addition, FRAP values did not change in samples containing $L b$. paracasei or commercial starter culture, while there was a decrease in these values in samples with $L b$. helveticus, Lb. rhamnosus B-442 or Lb. rhamnosus B-1445 compared to the FRAP values on the $1^{\text {st }}$ day of storage. At the end of storage, all fermented milk samples showed a decrease in FRAP values. In this study, the correlation between the values of FRAP and proteolysis degree was highly significant $(\mathrm{P}<$ 0.0001). The change in the proteolytic activity of Lactobacillus strains during storage affected the release of peptides from milk protein and consequently impacted the FRAP values of fermented milks. It was reported that increased proteolysis in fermented milk caused increased generation of bioactive peptides, which ultimately resulted in increased antioxidant capacity [22]. Ayyash et al. [20] reported that the fermentation of camel milk with indigenous camel milk probiotic LAB strains (Lb. reuteri-KX881777, Lb. plantarum-KX881772, Lb. plantarum-KX881779) showed maximum antioxidant activity compared to bovine milk.

\subsection{Viscosity}

Figure 7 shows the changes in the viscosity of fermented camel milks prepared using commercial starter culture and single strains of Lactobacillus during storage. The type of starter culture and storage duration significantly $(\mathrm{P}<0.05)$ affected the viscosity of fermented milk. All treatment showed a significant increase 


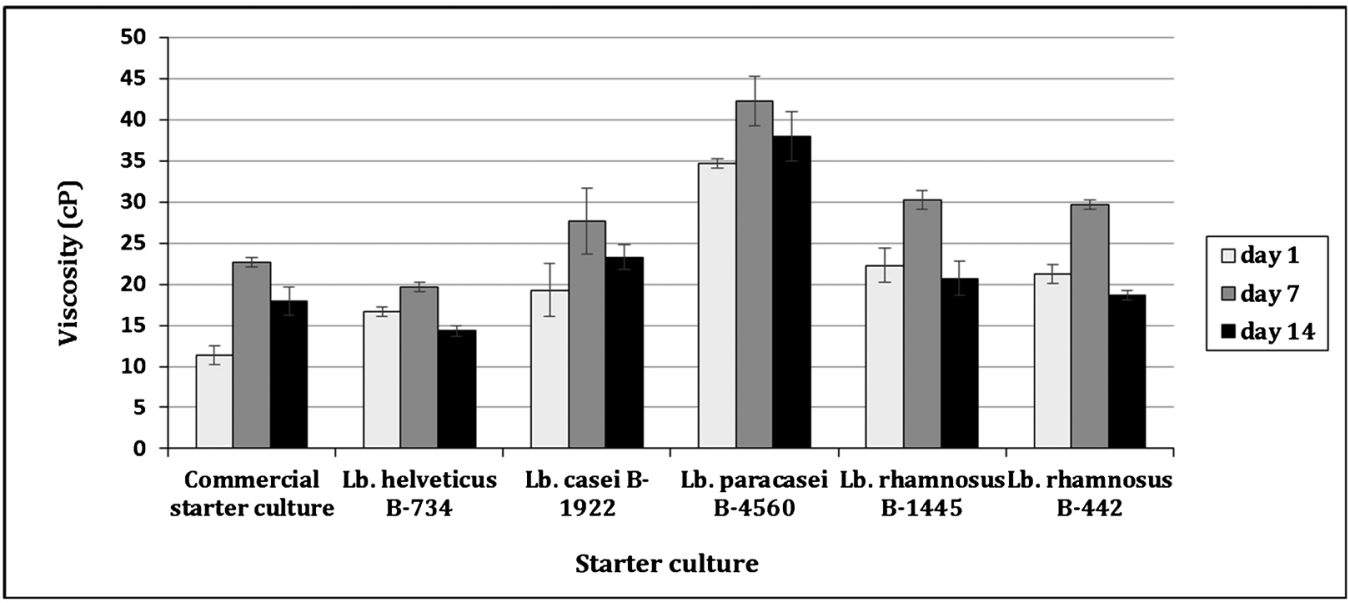

Figure 7. Changes in viscosity (Mean values $\pm \mathrm{SD}$ ) of fermented camel milks prepared using single strains of Lactobacillus during cold storage.

$(\mathrm{P}<0.05)$ in viscosity on the $7^{\text {th }}$ day of storage. Whereas, at the end of storage $\left(14^{\text {th }}\right.$ day $)$ the viscosity were significantly decreased $(\mathrm{P}<0.05)$ for all treatments. The highest viscosity was observed in $L b$. paracasei samples during the storage times, where the viscosity values were $34.7,42.3$ and $38.0 \mathrm{cP}$ on the $1^{\text {st }}, 7^{\text {th }}$ and $14^{\text {th }}$ day, respectively. On the other hand, lowest viscosity values were recorded with samples prepared with Lb. helveticus or commercial starter culture throughout storage. The decrease in viscosity may be due to the degradation of protein during storage [52]. Fguiri et al, [53] reported that the exopolysaccharide synthesized by lactic acid bacteria can improve the texture and viscosity of the final product. Kavas [54] indicated that the viscosity of yogurt increased with increasing acidity during storage.

\subsection{Sensory Evaluation}

The sensory attributes scores of fermented milks prepared using single strains of Lactobacillus during 14 days of storage period are presented in Table 2. The findings revealed that fermented milk samples varied significantly $(\mathrm{P}<0.05)$ in the mean values of taste scores. Fermented milks containing Lb. rhamnosus B442, Lb. rhamnosus B-1445 or commercial starter culture had the highest scores, while $L b$. helveticus samples were the lowest. Additionally, the color scores for $L b$. helveticus samples were the lowest, while the color scores of other samples were nearly similar. Previously, Moslehishad et al., [22] found that fermented camel milks using Lb. rhamnosus PTCC 1637, Lb. fermentum PTCC 1638 or Lb. plantarum PTCC 1058, had high average scores for sensory quality compared to those samples prepared by other tested strains. Buffa et al. [55] reported that the redundant proteolysis that occurs by highly proteolytic strains can cause uncontrolled formation of bitter peptides in the final product. The consistency scores of all fermented milks did not differ significantly $(\mathrm{P}>0.05)$, except for those samples with $L b$. helveticus on the $1^{\text {st }}$ day of storage, which obtained the lowest consistency scores $(\mathrm{P}<0.05)$. In terms of overall acceptability, 
Table 2. Sensory evaluation of fermented camel milks prepared using single strains of Lactobacillus during cold storage.

\begin{tabular}{|c|c|c|c|c|}
\hline \multirow[b]{2}{*}{ Starter culture } & \multicolumn{4}{|c|}{ Sensory attributes } \\
\hline & $\begin{array}{l}\text { Color } \\
(9)\end{array}$ & $\begin{array}{l}\text { Taste } \\
(9)\end{array}$ & $\begin{array}{c}\text { Consistency } \\
\text { (9) }\end{array}$ & $\begin{array}{c}\text { Overall } \\
\text { acceptability } \\
\text { (9) }\end{array}$ \\
\hline & \multicolumn{4}{|c|}{ Day 1} \\
\hline Commercial starter & $8.2 \pm 0.45^{\mathrm{aA}}$ & $8.2 \pm 0.84^{\mathrm{Aa}}$ & $8.0 \pm 0.71^{\mathrm{aA}}$ & $8.0 \pm 0.71^{\mathrm{aA}}$ \\
\hline Lb. helveticus B-734 & $6.7 \pm 0.58^{\mathrm{bA}}$ & $5.0 \pm 2.00^{\mathrm{bA}}$ & $6.3 \pm 0.58^{\mathrm{bA}}$ & $5.3 \pm 2.08^{\mathrm{cA}}$ \\
\hline Lb. casei subsp. casei $\mathrm{B}-1922$ & $8.0 \pm 0.00^{\mathrm{aA}}$ & $6.3 \pm 0.76^{\mathrm{bA}}$ & $7.1 \pm 0.69^{\mathrm{abA}}$ & $6.5 \pm 0.76^{\mathrm{cbA}}$ \\
\hline Lb. paracasei subsp. paracasei $\mathrm{B}-4560$ & $7.7 \pm 0.49^{\mathrm{aA}}$ & $6.1 \pm 1.46^{\mathrm{bA}}$ & $7.3 \pm 0.76^{\mathrm{abA}}$ & $6.5 \pm 1.61^{\mathrm{cbA}}$ \\
\hline Lb. rhamnosus B- 1445 & $7.9 \pm 0.38^{\mathrm{aA}}$ & $7.6 \pm 0.79^{\mathrm{aA}}$ & $7.3 \pm 0.49^{\mathrm{abA}}$ & $7.6 \pm 0.53^{\mathrm{abA}}$ \\
\hline \multirow[t]{2}{*}{ Lb. rhamnosus $\mathrm{B}-442$} & $7.9 \pm 0.38^{\mathrm{aA}}$ & $8.3 \pm 0.49^{\mathrm{aA}}$ & $7.0 \pm 1.00^{\mathrm{abA}}$ & $8.0 \pm 0.58^{\mathrm{aAB}}$ \\
\hline & \multicolumn{4}{|c|}{ Day 7} \\
\hline Commercial starter & $8.2 \pm 0.45^{\mathrm{aA}}$ & $7.4 \pm 0.89^{\mathrm{abA}}$ & $8.2 \pm 0.45^{\mathrm{aA}}$ & $8.0 \pm 0.71^{\mathrm{abA}}$ \\
\hline Lb. helveticus B-734 & $7.4 \pm 0.55^{\mathrm{bA}}$ & $2.0 \pm 0.82^{\mathrm{dB}}$ & $7.2 \pm 0.84^{\mathrm{aA}}$ & $2.4 \pm 0.89^{\mathrm{dB}}$ \\
\hline Lb. casei subsp. casei B-1922 & $8.0 \pm 0.00^{\mathrm{aA}}$ & $5.8 \pm 2.28^{\mathrm{cbA}}$ & $7.0 \pm 1.22^{\mathrm{aA}}$ & $6.2 \pm 2.05^{\mathrm{cbA}}$ \\
\hline Lb. paracasei subsp. paracasei $\mathrm{B}-4560$ & $8.2 \pm 0.45^{\mathrm{aA}}$ & $4.2 \pm 1.79^{\mathrm{cA}}$ & $7.6 \pm 0.55^{\mathrm{aA}}$ & $4.8 \pm 2.17^{\mathrm{cA}}$ \\
\hline Lb. rhamnosus B- 1445 & $8.0 \pm 0.00^{\mathrm{aA}}$ & $7.0 \pm 1.41^{\mathrm{abA}}$ & $7.6 \pm 0.89^{\mathrm{aA}}$ & $6.8 \pm 1.79^{\mathrm{abA}}$ \\
\hline \multirow[t]{2}{*}{ Lb. rhamnosus B- 442} & $8.2 \pm 0.45^{\mathrm{aA}}$ & $8.2 \pm 0.45^{\mathrm{aA}}$ & $7.8 \pm 0.84^{\mathrm{aA}}$ & $8.4 \pm 0.55^{\mathrm{aA}}$ \\
\hline & \multicolumn{4}{|c|}{ Day 14} \\
\hline Commercial starter & $8.0 \pm 0.82^{\mathrm{aA}}$ & $7.8 \pm 0.96^{\mathrm{aA}}$ & $7.8 \pm 0.96^{\mathrm{aA}}$ & $7.8 \pm 0.96^{\mathrm{aA}}$ \\
\hline Lb. helveticus B-734 & $6.5 \pm 1.73^{\mathrm{bA}}$ & $1.3 \pm 0.50^{\mathrm{cB}}$ & $7.0 \pm 1.83^{\mathrm{aA}}$ & $1.5 \pm 0.58^{\mathrm{cB}}$ \\
\hline Lb. casei subsp. casei $\mathrm{B}-1922$ & $8.0 \pm 0.82^{\mathrm{aA}}$ & $5.3 \pm 0.96^{\mathrm{bA}}$ & $7.5 \pm 1.29^{\mathrm{aA}}$ & $5.5 \pm 0.58^{\mathrm{bA}}$ \\
\hline Lb. paracasei subsp. paracasei $\mathrm{B}-4560$ & $8.0 \pm 0.82^{\mathrm{aA}}$ & $5.0 \pm 2.94^{\mathrm{bA}}$ & $8.3 \pm 0.96^{\mathrm{aA}}$ & $5.0 \pm 2.94^{\mathrm{bA}}$ \\
\hline Lb. rhamnosus B- 1445 & $8.0 \pm 0.82^{\mathrm{aA}}$ & $7.3 \pm 0.96^{\mathrm{abA}}$ & $8.3 \pm 0.96^{\mathrm{aA}}$ & $7.5 \pm 1.00^{\mathrm{Aa}}$ \\
\hline Lb. rhamnosus B-442 & $8.0 \pm 0.82^{\mathrm{aA}}$ & $7.3 \pm 1.26^{\mathrm{abA}}$ & $7.5 \pm 1.00^{\mathrm{aA}}$ & $7.3 \pm 1.26^{\mathrm{abB}}$ \\
\hline
\end{tabular}

Mean values ( \pm standard deviation) with different small letters within strains are significantly different at $\mathrm{P}$ $<0.05$; means with different capital letters within days are significantly different at $\mathrm{P}<0.05$.

samples prepared with $L b$. rhamnosus B-442, Lb. rhamnosus B-1445 or commercial starter culture obtained the highest scores, while fermented milks containing $L b$. helveticus were the lowest in overall acceptance. Pearson's correlation data revealed that there was an inverse correlation between the proteolysis degree and the scores of color $(\mathrm{P}=0.02)$, taste $(\mathrm{P}<0.0001)$, and overall acceptability $(\mathrm{P}=0.0003)$ of fermented milks. These results are in line with the findings of Amani et al. [56], who found that yogurts prepared using highly proteolytic strains had lower score of flavor, taste and overall acceptance than other samples produced using strains with low or medium proteolytic activity. However, these results disagree with the findings of Moslehishad et al., [22], who stated that there is no specific relationship between the proteolytic activity of selected LAB and flavor defects or overall acceptance of fermented cow and camel milk. The 
color and consistency scores were not affected by storage for all fermented milks. Also, the taste and overall acceptability scores remained stable during storage for all fermented milks except for samples containing $L b$. helveticus, as these scores decreased significantly $(\mathrm{P}<0.05)$ on the $14^{\text {th }}$ day of storage.

\section{Conclusion}

The antioxidant activity is very important for human health. In this study the improvement of the antioxidant properties of fermented camel milk was investigated using some strains of lactobacillus. From the results it could be concluded that $L b$. rhamnosus B-442 and Lb. rhamnosus B-1445 can be used to produce fermented camel milk with high antioxidant activity and acceptability.

\section{Acknowledgements}

The authors wish to express their sincere gratitude to Agriculture Research Service (ARS) Culture Collection, Norwegian Radio Relay League (NRRL), Peoria, USA for providing the bacterial strains free of charge. As well, the authors appreciate the assistance of prof. Dr. Hassan Zaky, Animal and Poultry Breeding Department, Desert Research Center for carrying out the statistical analysis of the results.

\section{Conflicts of Interest}

The authors declare no conflicts of interest regarding the publication of this paper.

\section{References}

[1] FAO Stat, 2019. http://www.fao.org/faostat/en/\#home

[2] Salami, M., Yousefi, R., Ehsani, M.R., Razavi, S.H., Chobert, J.M., Haertl, T., et al. (2009) Enzymatic Digestion and Antioxidant Activity of the Native and Molten Globule States of Camel $\beta$-Lactalbumin: Possible Significance for Use in Infant Formula. International Dairy Journal, 19, 518-523. https://doi.org/10.1016/j.idairyj.2009.02.007

[3] Bai, Y. and Zhao, D. (2015) The Acid-Base Buffering Properties of Alxa Bactrian Camel Milk. Small Ruminant Research, 123, 287-292. https://doi.org/10.1016/j.smallrumres.2014.10.011

[4] Quan, S., Tsuda, H. and Miyamoto, T. (2008) Angiotensin I-Converting Enzyme Inhibitory Peptides in Skim Milk Fermented with Lactobacillus helveticus 130B4 from Camel Milk in Inner Mongolia, China. Journal of the Science of Food and Agriculture, 88, 2688-2692. https://doi.org/10.1002/jsfa.3394

[5] Badkook, M.M. (2013) Fermented Camel Milk Reduces Inflammation in Rats Fed a High-Fat Diet. International Journal of Health Sciences and Research, 3, 7-17.

[6] Solanki, D. and Hati, S. (2018) Fermented Camel Milk: A Review on Its Bio-Functional Properties. Emirates Journal of Food and Agriculture, 30, 268-274. https://doi.org/10.9755/ejfa.2018.v30.i4.1661

[7] Berhe, T., Seifu, E., Ipsen, R., Kurtu, M.Y. and BechHansen, E. (2017) Processing Challenges and Opportunities of Camel Dairy Products. International Journal of 
Food Science, 2017, Article ID: 9061757. https://doi.org/10.1155/2017/9061757

[8] Donkor, O.N., Henriksson, A., Singh, T.K., Vasiljevic, T. and Shah, N.P. (2007) ACE-Inhibitory Activity of Probiotic Yoghurt. International Dairy Journal, 17, 13211331. https://doi.org/10.1016/j.idairyj.2007.02.009

[9] El-Sayed, M.I., Awad, S., Wahba, A., El Attar, A., Yousef, M.I. and Zedan, M. (2016) In Vivo Anti-Diabetic and Biological Activities of Milk Protein and Milk Protein Hydrolyaste. Advances in Dairy Research, 4, Article ID: 1000154.

[10] Awad, S., El-Sayed, M.I., Wahba, A., El Attar, A., Yousef, M.I. and Zedan, M. (2016) Antioxidant Activity of Milk Protein Hydrolyaste in Alloxan-Induced Diabetic Rats. Journal of Dairy Science, 99, 8499-8510. https://doi.org/10.3168/jds.2015-10626

[11] El-Sayed, M. and Awad, S. (2019) Milk Bioactive Peptides: Antioxidant, Antimicrobial and Anti-Diabetic Activities. Advances in Biochemistry, 7, 22-33. https://doi.org/10.11648/j.ab.20190701.15

[12] Jrad, Z., Girardet, J.M., Adt, I., Oulahal, N., Degraeve, P., Khorchani, T. and El Hatm, H. (2014) Antioxidant Activity of Camel Milk Casein before and after in Vitro Simulated Enzymatic Digestion. Mljekarstvo, 64, 287-294. https://doi.org/10.15567/mljekarstvo.2014.0408

[13] Phelan, M., Aherne, A., FitzGerald, R.J. and O’Brien, N.M. (2009) Casein-Derived Bioactive Peptides: Biological Effects, Industrial Uses, Safety Aspects and Regulatory Status. International Dairy Journal, 19, 643-654. https://doi.org/10.1016/j.idairyj.2009.06.001

[14] Pimentel, F.B., Cermeño, M., Kleekayai, T., Harnedy, P., et al. (2020) Effect of in Vitro Simulated Gastrointestinal Digestion on the Antioxidant Activity of the Red Seaweed Porphyra dioica. Food Research International, 136, Article ID: 109309. https://doi.org/10.1016/j.foodres.2020.109309

[15] Zhou, D., Zhu, B., Lu, Q., Wu, H., Li, D., Yang, J., et al. (2012) In Vitro Antioxidant Activity of Enzymatic Hydrolysates Prepared from Abalone (Haliotis discus hannai Ino) Viscera. Food and Bioproducts Processing, 90, 148-154. https://doi.org/10.1016/j.fbp.2011.02.002

[16] Savijoki, K., Ingmer, H. and Varmanen, P. (2006) Proteolytic Systems of Lactic Acid Bacteria. Applied Microbiology and Biotechnology, 71, 394-406. https://doi.org/10.1007/s00253-006-0427-1

[17] Kunji, E.R.S., Mierau, I., Hagting, A., Poolman, B. and Konings, N. (1996) The Proteolytic System of Lactic Acid Bacteria. Antonie Leeuwenhoek, 70, 187-221. https://doi.org/10.1007/BF00395933

[18] Bahobail, A.S., Ali, A.A. and Alyan, A.A. (2014) Effect of Fermentation Process on the Improvement of Nutrition Value of Camel Milk. International Journal of Multidisciplinary and Current Research, 2, 78-82.

[19] Moslehishad, M., Ehsani, M.R., Salami, M., Mirdamadi, S., Ezzatpanah, H., Naslaji, A.N. and Moosavi-Movahedi, A.A. (2013) The Comparative Assessment of ACEInhibitory and Antioxidant Activities of Peptide Fractions Obtained from Fermented Camel and Bovine Milk by Lactobacillus rhamnosus PTCC 1637. International Dairy Journal, 29, 82-87. https://doi.org/10.1016/j.idairyj.2012.10.015

[20] Ayyash, M., Al-Nuaimi, A.K., Al-Mahadin, S. and Liu, S.Q. (2017) In Vitro Investigation of Anticancer and ACE-Inhibiting Activity, $\alpha$-Amylase and $\alpha$-Glucosidase Inhibition, and Antioxidant Activity of Camel Milk Fermented with Camel Milk Probiotic: A Comparative Study with Fermented Bovine Milk. Food Chemistry, 239, 588-597. https://doi.org/10.1016/j.foodchem.2017.06.149 
[21] Kansci, G., Genot, C., Meynier, A., Gaucheron, F. and Chobert, J.M. (2004) B-Caseinophosphopeptide (f1-25) Confers on $\beta$-Casein Tryptic Hydrolysate an Antioxidant Activity during Iron/Ascorbate-Induced Oxidation of Liposomes. Lait, 84, 449462. https://doi.org/10.1051/lait:2004019

[22] Moslehishad, M., Mirdamadi, S., Ehsani, M.R., Ezzatpanah, H. and Moosavimovahed, A.A. (2013) The Proteolytic Activity of Selected Lactic Acid Bacteria in Fermenting Cow's and Camel's Milk and the Resultant Sensory Characteristics of the Products. International Journal of Dairy Technology, 66, 279-285.

https://doi.org/10.1111/1471-0307.12017

[23] Salami, M., Moosavi-Movahedi, A.A., Moosavi-Movahe-di, F., Ehsani, M.R., Yousefi, R., Fahadi, M., Niasari-Nasl-aji, A., Saboury, A.A., Chobert, J.M. and Haertlé, T. (2011) Biological Activity of Camel Milk Casein Following Enzymatic Digestion. Journal of Dairy Research, 78, 471-487. https://doi.org/10.1017/S0022029911000628

[24] Tamime, A.Y. and Robinson, R.K. (2007) Tamime and Robinson's Yoghurt: Science and Technology. 3rd Edition, Woodhead Publishing Limited, Cambridge, 11-118.

[25] AOAC (2005) Official Methods of Analysis of the Association Analytical Chemists. 18th Edition, Association of Official Analytical Chemistry, Gaithersburg.

[26] Shori, A.B. and Baba, A.S. (2013) Antioxidant Activity and Inhibition of Key Enzymes Linked to Type-2 Diabetes and Hypertension by Azadirachta indica-Yogurt. Journal of Saudi Chemical Society, 17, 295-301. https://doi.org/10.1016/j.jscs.2011.04.006

[27] Folkertsma, B. and Fox, P.F. (1992) Use of the Cd-Ninhydrin Reagent to Assess Proteolysis in Cheese during Ripening. Journal of Dairy Research, 59, 217-224. https://doi.org/10.1017/S0022029900030466

[28] Laemmli, U.K. (1970) Cleavage of Structural Proteins during the Assembly of the Head of Bacteriophage T4. Nature, 277, 680-685. https://doi.org/10.1038/227680a0

[29] Abirami, A., Nagarani, G. and Siddhuraju, P. (2014) In Vitro Antioxidant, Antidiabetic, Cholinesterase and Tyrosinase Inhibitory Potential of Fresh Juice from Citrus hystrix and C. maxima Fruits. Food Science and Human Wellness, 3, 16-25. https://doi.org/10.1016/j.fshw.2014.02.001

[30] Lim, Y.Y. and Quah, E.P.L. (2007) Antioxidant Properties of Different Cultivars of Portulaca oleracea. Food Chemistry, 103, 734-740. https://doi.org/10.1016/j.foodchem.2006.09.025

[31] Chan, E.W.C., Lim, Y.Y. and Chew, Y.L. (2007) Antioxidant Activity of Camellia sinensis Leaves and Tea from a Lowland Plantation in Malaysia. Food Chemistry, 102, 1214-1222. https://doi.org/10.1016/j.foodchem.2006.07.009

[32] Oyaizu, M. (1986) Studies on Products of Browning Reaction: Antioxidative Activities of Products of Browning Reaction Prepared from Glucosamine. Japan Journal of Nutrition, 44, 307-315. https://doi.org/10.5264/eiyogakuzashi.44.307

[33] Papadimitriou, C.G., Mastrojiannaki, A.V., Silva, A.V., Gomes, A.M., Malcata, F.X. and Alichanidis, E. (2007) Identification of Peptides in Traditional and Probiotic Sheep Milk Yoghurt with Angiotensin I-Converting Enzyme (ACE)-Inhibitory Activity. Food Chemistry, 105, 647-656. https://doi.org/10.1016/j.foodchem.2007.04.028

[34] Al-Sheraji, S.H., Ismail, A., Manap, M.Y., Mustafa, S., Yusof, R.M. and Hassan, F.A. (2013) Prebiotics as Functional Foods: A Review. Journal of Functional Foods, 5, 1542-1553. https://doi.org/10.1016/j.jff.2013.08.009

[35] Shori, A.B. (2013) Antioxidant Activity and Viability of Lactic Acid Bacteria in Soybean-Yogurt Made from Cow and Camel Milk. Journal of Taibah University for 
Science, 7, 202-208. https://doi.org/10.1016/j.jtusci.2013.06.003

[36] De-Oliveira, M.N. (2014) Fermented Milks and Yogurt (in Fermented Milks). In: Batt, C. and Batt, C.A., Eds., Encyclopedia of Food Microbiology, 2nd Edition, Academic Press, London, 908-922.

https://doi.org/10.1016/B978-0-12-384730-0.00121-X

[37] Sasaki, M., Bosman, B.W. and Tan, P.S.T. (1995) Comparison of Proteolytic Activities in Various Lactobacilli. Journal of Dairy Research, 62, 601-610. https://doi.org/10.1017/S0022029900031332

[38] Griffiths, M.W. and Tellez, A.M. (2013) Lactobacillus helveticus: The Proteolytic System. Frontiers in Microbiology, 4, 1-9. https://doi.org/10.3389/fmicb.2013.00030

[39] El-Zahar, K., Sitohy, M., Dalgalarrondo, M., Choiset, Y., Métro, F., et al. (2004) Purification and Physicochemical Characterization of Ovine $\beta$-Lactoglobulin and $\alpha$ Lactalbumin. Nahrung/ Food, 48, 177-183. https://doi.org/10.1002/food.200300447

[40] Li, S., Tang, S., He, Q., Hu, J. and Zheng, J. (2019) Changes in Proteolysis in Fermented Milk Produced by Streptococcus thermophilus in Co-Culture with Lactobacillus plantarum or Bifidobacterium animalis subsp. lactis during Refrigerated Storage. Molecules, 24, 3699. https://doi.org/10.3390/molecules24203699

[41] Ainsworth, E.A. and Gillespie, K.M. (2007) Estimation of Total Phenolic Content and Other Oxidation Substrates in Plant Tissues Using Folin-Ciocalteu Reagent. Nature Protocols, 2, 875-877. https://doi.org/10.1038/nprot.2007.102

[42] Virtanen, T., Pihlanto, A., Akkanen, S. and Korhonen, H. (2007) Development of Antioxidant Activity in Milk Whey during Fermentation with Lactic Acid Bacteria. Journal of Applied Microbiology, 102, 106-115. https://doi.org/10.1111/j.1365-2672.2006.03072.x

[43] Alemán, A., Giménez, B., Pérez-Santin, E., Gómez-Guillén, M. and Montero, P. (2011) Contribution of Leu and Hyp Residues to Antioxidant and ACE-Inhibitory Activities of Peptide Sequences Isolated from Squid Gelatin Hydrolysate. Food Chemistry, 125, 334-341. https://doi.org/10.1016/j.foodchem.2010.08.058

[44] Namdari, A. and Nejati, F. (2016) Development of Antioxidant Activity during Milk Fermentation by Wild Isolates of Lactobacillus helveticus. Applied Food Biotechnology, 3, 178-186.

[45] Yilmaz-Ersan, L., Ozcan, T., Akpinar-Bayizit, A. and Sahin, S. (2016) The Antioxidative Capacity of Kefir Produced from Goat Milk. International Journal of Chemical Engineering and Applications, 7, 22-26. https://doi.org/10.7763/IJCEA.2016.V7.535

[46] Barac, M., Vucic, T., Zilic, S., Pesic, M., Sokovic, M., Petrovic, J., Kostic, A., Ignjatovic, I.S. and Milincic, D. (2019) The Effect of in Vitro Digestion on Antioxidant, ACE-Inhibitory and Antimicrobial Potentials of Traditional Serbian White-Brined Cheeses. Foods, 8, 94. https://doi.org/10.3390/foods8030094

[47] Abd El-Fattah, A., Sakr, S., El-Dieb, S.M. and Elkashef, H. (2017) Biological Activities of Lactobacilli Relevant to Cardiovascular Health in Skim Milk. Food Science and Biotechnology, 26, 1613-1623. https://doi.org/10.1007/s10068-017-0219-7

[48] Abou-Soliman, N.H.I. (2020) The Impact of Using Some Adjunct Cultures on the Quality of Fermented Camel Milk Fortified with Iron. Journal of Food and Dairy Science, Mansoura University, 11, 251-257. https://doi.org/10.21608/jfds.2020.118364

[49] Walters, M.E., Esfandi, R. and Tsopmo, A. (2018) Potential of Food Hydrolyzed Proteins and Peptides to Chelate Iron or Calcium and Enhance Their Absorption. Foods, 7, 172. https://doi.org/10.3390/foods7100172 
[50] Zhang, T., Li, Y., Miao, M. and Jiang, B. (2011) Purification and Characterisation of a New Antioxidant Peptide from Chickpea (Cicer arietium L.) Protein Hydrolysates. Food Chemistry, 128, 28-33. https://doi.org/10.1016/j.foodchem.2011.02.072

[51] Zhu, K.X., Su, C.Y., Guo, X.N., Peng, W. and Zhou, H.M. (2011) Influence of Ultrasound during Wheat Gluten Hydrolysis on the Antioxidant Activities of the Resulting Hydrolysate. International Journal of Food Science and Technology, 46, 1053-1059. https://doi.org/10.1111/j.1365-2621.2011.02585.x

[52] Putri, Y.D., Setianim, N.A. and Warya, S. (2020) The Effect of Temperature, Incubation and Storage Time on Lactic Acid Content, $\mathrm{pH}$ and Viscosity of Goat Milk Kefir. Current Research on Biosciences and Biotechnology, 2, 101-104.

https://doi.org/10.5614/crbb.2020.2.1/HPMQ5042

[53] Fguiri, I., Ziadi, M., Abassi, M., Arroum, S. and Khorchani, T. (2012) Suitability of Camel Milk to Transformation in Leben by Lactic Starter. African Journal of Microbiology Research, 6, 7185-7192.

[54] Kavas, N. (2016) Yoghurt Production from Camel (Camelus dramedarius) Milk Fortified with Samphire Molasses and Different Colloids. Mljekarstvo, 66, 34-47. https://doi.org/10.9734/BJAST/2016/23683

[55] Buffa, M., Morais, J., Jiménez-Belenguer, A., Hernández-Giménez, E. and Guamis, B. (2005) Technological Characterization of Lactic Acid Bacteria Isolated from Raw Ewes' Milk for Cheese Making. Milchwissenschaft, 61, 404-407.

[56] Amani, E., Eskandari, M.H. and Shekarforoush, S. (2017) The Effect of Proteolytic Activity of Starter Cultures on Technologically Important Properties of Yogurt. Food Science \& Nutrition, 5, 525-537. https://doi.org/10.1002/fsn3.427 